\title{
LENDO VOZES NO PARQUE, DE ANTHONY BROWNE: UM ESTUDO DA RECEPÇÃO POR CRIANÇAS DE DIFERENTES CONTEXTOS
}

\author{
READING VOICES IN THE PARK, BY ANTHONY BROWNE: \\ A STUDY OF RECEPTION BY CHILDREN FROM DIFFERENT \\ CONTEXTS
}

\author{
Rosa Maria Hessel SILVEIRA* \\ Darlize Teixeira de MELLO** \\ Liége Freitas BARBOSA***
}

\begin{abstract}
Resumo: Picture books, em inglês, libros-álbum, em espanhol, e livros ilustrados, em português, no Brasil, são obras infantis de surgimento mais recente em que há uma estreita articulação entre texto e ilustrações, com narrativa construída pela conjugação das duas linguagens (VAN DER LNDEN, 2011; NIKOLAJEVA; SCOTT, 2011; SALISBURY; STYLES, 2013). Um dos escritores contemporâneos mais destacados nessa vertente, Anthony Browne escreveu Vozes no parque, livro em que um mesmo episódio é narrado por quatro vozes de participantes de uma cena cotidiana, que envolve relacionamentos entre pessoas, questões de classe social e geração. O presente estudo, tendo como horizonte a questão "como as crianças leem livros ilustrados?", objetiva analisar e comparar sessões de leitura compartilhada da obra, realizadas com alunos de escolas públicas de Porto Alegre, Brasil, com informações sobre sessões de leitura realizadas em duas escolas públicas de Buenos Aires, Argentina, e relatadas em Thomson (2016). Tal estudo resulta de pesquisa apoiada pelo CNPq, que envolveu sessões de leitura e discussão de obras literárias. Ambos os estudos - brasileiro e argentino - inspiram-se em obras de Chambers $(2007$; 2008) e outros autores que enfatizam o partilhamento da leitura literária. A análise comparativa permitiu verificar pontos de contato entre as diferentes recepções, como sobre: 1) a percepção da polifonia estrutural da obra; 2) a questão de fundo da desigualdade social, e 3) aspectos inusitados das ilustrações. $\mathrm{O}$ estudo permitiu realizar inferências sobre as potencialidades de leitura dos livros ilustrados e aponta para a sua riqueza, em especial, quando conta com uma mediação adequada do adulto.
\end{abstract}

Palavras-chave: Vozes no parque. Anthony Browne. Livros ilustrados. Literatura infantil. Comparação de leituras.

Abstract: Picture books, in English, libros-álbum, in Spanish and livros ilustrados, in Brazilian Portuguese, are a recent type of children books that present a close association between written texts and pictures so that the narrative is constructed from a symbiosis between them (Van der Linden, Nikolajeva \& Scott, Salisbury \& Styles). Anthony Browne, who is one of the most renowned contemporary writers of this genre, wrote Voices in the park, in which one single everyday scene involving relationships among people cut across by social class and generation issues is narrated by four participating voices. This paper presents the results of a CNPq-supported research project involving

\footnotetext{
* Professora do Programa de Pós-Graduação em Educação da Universidade Federal do Rio Grande do Sul (UFRGS). Doutorado em Educação pela UFRGS. E-mail: rosamhs@ @mail.com.br. ORCID: http://orcid.org/00000001-5797-6627.

** Professora do Programa de Pós-Graduação em Educação da Universidade Luterana do Brasil (ULBRA). Doutorado em Educação pela Universidade Federal do Rio Grande do Sul (UFRGS). E-mail: darlizemello@ terra.com.br. ORCID: http://orcid.org/0000-0002-6741-6727.

**** Doutoranda no Programa de Pós-Graduação em Educação da Universidade Federal do Rio Grande do Sul. E-mail: liegebarbosa@gmail.com. ORCID: https://orcid.org/0000-0003-3784-2423.
} 
reading sessions and discussions (mediated conversation) of literary works. The study aimed to answer the question "How do children read picturebooks?" by analysing and comparing shared reading sessions carried out with fifth-grade students at public schools in Porto Alegre, Brazil, with data from reading sessions at two public schools in Buenos Aires, Argentina, as reported in Thomson (2016). Both studies - Brazilian and Argentinian research - drew on Chambers $(2007 ; 2008)$ and other studies on literary reading sharing. The comparative analysis revealed points of contact between the readings in different contexts, especially about: i) the perception of polyphonic structures of the work; ii) the backgrounded social inequality and iii) the unexpectedness of some pictures. Inferences could be drawn about potentialities richness of reading picture books and especially when it includes adequate adult mediation.

Keywords: Voices in the Park. Anthony Browne. Picture books. Children literature. Comparing reading.

\section{Literatura para crianças e os livros ilustrados}

Livros para crianças, no imaginário corrente, são livros que se caracterizam pela presença abundante de ilustrações, de preferência coloridas, e pode-se afirmar que a associação da imagem à ludicidade e o entendimento de que ela é inferior, em sua complexidade, à palavra escrita, também contribuíram e contribuem para a desvalorização da literatura infantil no campo literário. Tal desprestígio já foi bastante discutido no campo dos estudos da literatura para crianças - e outros fatores como sua frequente contaminação pelo lastro pedagógico, suas íntimas relações com interesses mercadológicos, assim como a sua assimetria de origem, também colaboraram/colaboram para sua depreciação naquele campo. Sem que seja nosso intuito retomarmos e aprofundarmos tal discussão neste momento, nosso objetivo é de voltarmos nosso olhar para um gênero de livros infantis, de surgimento relativamente recente, cujos atributos estéticos justamente emergem da articulação estreita entre imagem e palavra trata-se dos chamados picturebooks (em Inglês), libros-álbum (em Espanhol) e livros ilustrados, na tradução mais corrente, mas não consensual, no Brasil. Observe-se, como informa Van der Linden (2011, p. 23), a existência de preferência pelo termo ‘álbum' em algumas línguas, como no francês: "album ou livre d'images", em Portugal: "álbum ilustrado" e, em espanhol, como acima mencionamos, "álbum” ou "libro-álbum”.

A alusão à expressão "livros ilustrados" e a menção a um surgimento relativamente recente - Arizpe e Styles, em 2004, se referem aos "últimos 20 anos" - podem causar algum espanto a quem não circula na área - afinal, já há vários séculos os livros para crianças não recebem ilustrações, ainda que sem a pujança dos atuais recursos gráficos? A resposta a tal dúvida vem do fato de que tem se optado, no campo da crítica de literatura infantil, por reservar a expressão "livros ilustrados" (tradução de picturebooks) para aquelas obras em que a narrativa se constrói conjuntamente pelo texto verbal e ilustração, enquanto para obras em que as 
ilustrações - mesmo com qualidade - não desempenham um papel tão importante quanto o texto verbal para a compreensão da narrativa, reserva-se a expressão "livros com ilustrações" (tradução de illustrated book, book with pictures). Um livro infantil com ilustrações pode receber novas edições, mantendo o mesmo texto verbal, mas com um novo projeto gráfico e novas ilustrações, como ocorre com obras de Monteiro Lobato, Ruth Rocha, Ana Maria Machado e tantos outros autores reconhecidos. Para marcar melhor esta distinção, Van der Linden (2011, p. 24) define "livros com ilustração" como "obras que apresentam um texto acompanhado de ilustrações. O texto é espacialmente predominante e autônomo do ponto de vista do sentido. O leitor penetra na história por meio do texto, o qual sustenta a narrativa". Já no livro ilustrado, "a narrativa se faz de maneira articulada entre texto e imagens" (VAN DER LINDEN, 2011, p. 24), e, conforme Nikolajeva e Scott (2011), o caráter singular dos livros ilustrados baseia-se na combinação de dois tipos de comunicação paralelos - o verbal e o visual -, lançando mão de dois conjuntos distintos de signos - o icônico e o convencional.

Salisbury e Styles (2013), após detida análise da evolução do impresso ilustrado no mundo ocidental, realiza uma breve discussão sobre o status dos atuais livros ilustrados como arte. Para os autores, o livro ilustrado contemporâneo "começa a preencher uma lacuna na arte gráfica narrativa e representacional" (p. 49), e "os melhores livros ilustrados tornam-se pequenas galerias de arte atemporais em nossas casas - uma mistura de conceito, arte, design e produção, que gera prazer e estimula a imaginação de crianças e adultos” (p. 50).

Outra dimensão importante nos livros ilustrados modernos reside no caráter diferenciado do processo de leitura que eles desencadeiam. Para Patrícia Berdichevsky (apud Thomson, 2016, p. 21), o livro ilustrado "propõe diferentes formas de olhar, uma poética diferente" (p. 21, tradução nossa $)^{1}$. De maneira sintética, mas que serve de ponto de partida para o estudo que aqui desenvolveremos, Maria Cristina Thomson assim descreve a ação do leitor do livro ilustrado:

\footnotetext{
Em suma, é um tipo de livro que demanda um leitor disposto a percorrer um caminho de ida e volta e a animar-se com o jogo que lhe é proposto pelo vaivém permanente entre a imagem visual e o texto escrito [...]. Este transitar sinuoso, sem dúvida, o expõe a um desafio particular [...] construir significado atendendo simultaneamente às demandas apresentadas pela interpretação das duas linguagens em ação. (THOMSON, 2016, p. 41, tradução nossa) $)^{2}$.
}

\footnotetext{
${ }^{1}$ No original: "propone modos de mirar diferentes, una poética distinta".

${ }^{2}$ No original: "En sínteses, es un tipo de libro que demanda un lector dispuesto a recorrer un camino de ida y vuelta y animarse al juego que se le propone el permanente vaivén entre la imagen visual y el texto escrito [...]. Este transitar sinuoso, sin duda, lo expone a um desafio particular [...] construir significado atendendo simultaneamente a las demandas que le presenta la interpretación de los dos lenguajes em acción".
} 
Se, por um lado, os livros ilustrados contemporâneos capturam o interesse e provocam tanto entusiasmo entre a crítica de literatura infantil (vejam-se, por exemplo, Salisbury e Styles, 2013; Nikolajeva e Scott, 2011; Van der Linden, 2011 e Arizpe e Styles, 2004), por outro lado, torna-se relevante perscrutar os desafios e os caminhos empreendidos pelos pequenos leitores na sua recepção. Enfim, como se dá a leitura dos livros ilustrados pelas crianças? Ainda que já existam alguns estudos sobre a questão, eles são pouco frequentes no Brasil, e é neste campo que se situa o interesse do presente artigo, o qual envereda pela discussão das possibilidades de leitura de uma obra de um dos mais destacados autores contemporâneos de livros ilustrados Anthony Browne, qual seja Vozes no parque (no original, Voices in the Park). Seu objetivo é o de analisar percursos de leitura e discussão da obra Vozes no parque, realizadas em sessões de leitura compartilhada com alunos de $5^{\circ}$ ano de duas escolas públicas de Porto Alegre/RS/Brasil, cotejando-os com informações sobre sessões de leitura da mesma obra realizadas em duas escolas, também públicas, de Buenos Aires/Argentina e relatadas na obra de Thomson (2016). A oportunidade propiciada pelo relato e análise da pesquisadora argentina, com metodologia de trabalho de discussão semelhante ao de nossa pesquisa - inspirados ambos em Chambers (2007, 2008) e sua ênfase nas conversas sobre leitura - motivou a realização do presente estudo, na medida em que expande as possibilidades de resposta a uma pergunta de base: como crianças de diferentes realidades respondem a um mesmo livro ilustrado, por sua vez produzido em outro continente? Correlacionada com as possíveis respostas a esta questão, avulta uma outra dimensão, articulada às preocupações com a educação ou letramento literário: o que os dados destes gestos de leitura podem nos ensinar sobre uma mediação adequada em relação a livros ilustrados?

Para desenvolvermos o artigo, o texto apresenta, a seguir, uma seção que contextualiza a pesquisa, o autor e a obra específica que é objeto da leitura infantil. Já na seção seguinte, realizase uma aproximação entre a discussão e observações, tanto das crianças brasileiras quanto das argentinas, em relação a três categorias principais: a percepção da polifonia estrutural da obra; a questão de fundo da desigualdade social e as leituras suscitadas por aspectos inusitados das ilustrações. Observações finais encerram o trabalho.

\section{Contextualização da pesquisa}

O trabalho de mediação de leitura com Vozes no parque, de Anthony Browne (2014) está inserido em pesquisa mais ampla, intitulada "Percursos e representações da infância em livros 
para crianças - estudo de obras e leituras" (apoio CNPq) $)^{3}$, que dá sequência a um programa de pesquisas sobre literatura infantil e leituras de obras escolhidas por crianças de escolas públicas, em desenvolvimento no grupo de pesquisa do Núcleo de Estudos sobre Currículo, Cultura e Sociedade (NECCSO/UFRGS). A pesquisa, interinstitucional, tinha como objetivo geral analisar os gestos de compreensão leitora de alunos dos anos iniciais de escolas públicas, frente a um conjunto delimitado de obras ficcionais em circulação. O público-alvo abrangeu alunos entre 9 e 12 anos do $4^{\circ}$ e $5^{\circ}$ anos do Ensino Fundamental de duas escolas públicas de Porto Alegre/RS, sendo uma escola pertencente à rede municipal de ensino ${ }^{4}$ - Escola 1 - e outra, à rede estadual de ensino ${ }^{5}$ - Escola 2.

Em uma de suas instâncias, a pesquisa envolvia sessões de leitura e discussão (conversas mediadas) de obras anteriormente selecionadas por critérios como qualidade estética, variedade de temáticas, abordagens e autores, e - em especial - pela presença de personagens crianças como protagonistas. Em linhas gerais, o trabalho em sala de aula sucedia da seguinte forma: cada dupla de alunos recebia um exemplar da obra trabalhada de forma a ter acesso ao livro em sua materialidade e ao texto, que seria lido de forma compartilhada. Em uma conversa prévia com a turma, ativavam-se algumas estratégias de predição, a fim de introduzir brevemente o tema do livro e esclarecer possíveis palavras ou expressões que pudessem ser estranhas ao vocabulário das crianças. Na sequência, uma das pesquisadoras fazia a leitura em voz alta, acompanhada das crianças, e, em seguida, fazia-se uma "releitura" da obra, página a página, na qual elas eram desafiadas com perguntas sobre as ilustrações. Por fim, realizava-se uma discussão mais geral sobre o livro. Tal discussão inspirava-se em autores atuais, como Chambers (2007, 2008), que enfatizam o incentivo para os alunos dialogarem e trocarem pontos-de-vista, considerando-se a troca de ideias e de impressões sobre o texto e as ilustrações. Associados à leitura compartilhada e à conversa, também eram desenvolvidos trabalhos variados (textos, desenhos, colagens), cujo principal enfoque era a articulação de aspectos do livro à experiência pessoal de cada criança ${ }^{6}$. Entre os pressupostos que conferem sustentação a

\footnotetext{
${ }^{3}$ O projeto aqui mencionado foi examinado e aprovado no Comitê de Ética em Pesquisa da Universidade Federal do Rio Grande do Sul (UFRGS), tendo seguido todos os trâmites referentes à obtenção de Termos de Consentimento e Termos de Assentimento das crianças e seus responsáveis. Por questões de sigilo, não há identificação nem de escolas nem de alunos.

${ }^{4}$ A turma era constituída por 29 alunos, provenientes de lares com nível socioeconômico baixo. A referida Escola localiza-se na periferia urbana de Porto Alegre. Esse grupo de alunos já estava participando da pesquisa desde o $4^{\circ}$ ano.

${ }^{5}$ A turma era constituída por 20 alunos, provenientes de lares com nível socioeconômico baixo e médio baixo. A referida Escola localiza-se em bairro considerado central de Porto Alegre.

${ }^{6} \mathrm{~A}$ metodologia que fundamenta a pesquisa é de cunho qualitativo (Bauer; Gaskell, 2002), e os dados recolhidos e analisados incluem detalhes descritivos de conversas e escritas sobre leitura, no contexto de uma sala de aula. Foram utilizadas gravações em vídeo, diário de campo e registros escritos dos alunos.
} 
tal metodologia, está o entendimento de que é na linguagem e na relação com o outro que os sentidos são produzidos e os processos de subjetivação se efetivam. "Enfim, para além do próprio leitor e do texto, as múltiplas formas de relação entre os leitores e as leituras são constituídas nas/pelas práticas sociais e nas inúmeras possibilidades de mediação da leitura" (NOGUEIRA; LAPLANE, 2017, p. 16).

Neste trabalho, nossa proposta é comparar dados obtidos na pesquisa brasileira com dados de leitura e discussão da mesma obra realizadas em duas escolas, também públicas, de Buenos Aires/Argentina. Os dados da pesquisa argentina são trazidos pela pesquisadora e autora María Cristina Thomson, no livro Sobre Lineas (2016), no qual a professora compartilha suas experiências de pesquisa com o livro-álbum em sala de aula. O trabalho com Vozes no parque (em sua tradução espanhola) foi realizado com alunos do quinto ano das escolas Presidente Mitre (identificada como EPM) e da Escola Evaristo Julio Badía (identificada como EEJB), de Buenos Aires; a análise focalizou as respostas e interações das crianças em relação à leitura de imagens visuais, à interpretação do texto linguístico e icônico e suas reflexões sobre o tema da história do livro.

Em entrevista ${ }^{7}$ em que relata o trabalho com o livro-álbum nas escolas argentinas, Thomson reitera que um livro ilustrado, como Vozes no parque, requer um leitor bastante ativo, “capaz de preencher as lacunas de informação que tanto o código da imagem visual quanto o código do texto escrito apresentam" (THOMSON, 2016, s/p, tradução nossa) ${ }^{8}$. Nesse sentido, ganha importância o papel da conversa e da mediação realizada por professores e/ou pesquisadores: "Acredito que o espaço de troca dialógica que o mediador ou professor planeja para a leitura compartilhada dos livros ilustrados deve promover uma autêntica prática sociocultural, onde a confiança mútua da criança-adulto prevaleça para se expressar com total liberdade" (THOMSON, 2016, s/p, tradução nossa $)^{9}$, destaca a pesquisadora. Anteriormente às análises das conversas sobre a obra, faremos uma breve caracterização do livro ilustrado Vozes no parque.

\footnotetext{
7 Entrevista concedida à revista La Primera Piedra em 2016. Disponível em: https://www.laprimerapiedra.com.ar/2016/05/lineas-libro-album-aula-redescubriendo-otros-rincones-laliteratura-infantil/. Acesso em 05 de maio de 2020.

${ }^{8}$ No original: "[...] requiere un lector muy activo, capaz de rellenar los huecos de información que tanto el código de la imagen visual como el del texto escrito le presentan".

${ }^{9}$ No original: "Creo que el espacio de intercambio dialógico que el mediador o docente planifica para la lectura compartida de los libros-álbum, debe propiciar una auténtica práctica sociocultural donde prevalezca la mutua confianza niño-adulto para expresarse con entera libertad".
} 


\section{Breve caracterização da obra}

Vozes no parque ${ }^{10}$, escrito pelo premiado e prolífico escritor inglês Anthony Browne, pode ser considerado mais que um livro: é como um objeto artístico com uma narrativa que se vale de uma linguagem híbrida composta por imagem e texto. Em suas obras, algumas delas traduzidas $^{11}$ para português, Browne é tanto ilustrador quanto autor do texto, o que lhe possibilita notável articulação entre ambos. Assim, para o autor, palavras e imagens devem ser desenvolvidas ao mesmo tempo (GARRALÓN, 2014). Vozes no parque é uma história atemporal contada por quatro personagens sobre um passeio no parque, sendo que cada um vivencia o passeio a partir de seu ponto de vista. Em um primeiro momento, este parece ser um tema comum; no entanto, o cotidiano "passeio no parque" toma uma dimensão especial, tanto em função da inusitada narrativa de quatro pontos-de-vista sobre os mesmos eventos, quanto pelas inúmeras sugestões simbólicas das ilustrações e seus elementos (cores, planos, ângulos, sombras etc.).

Figura 1 - Capa do livro Vozes no parque

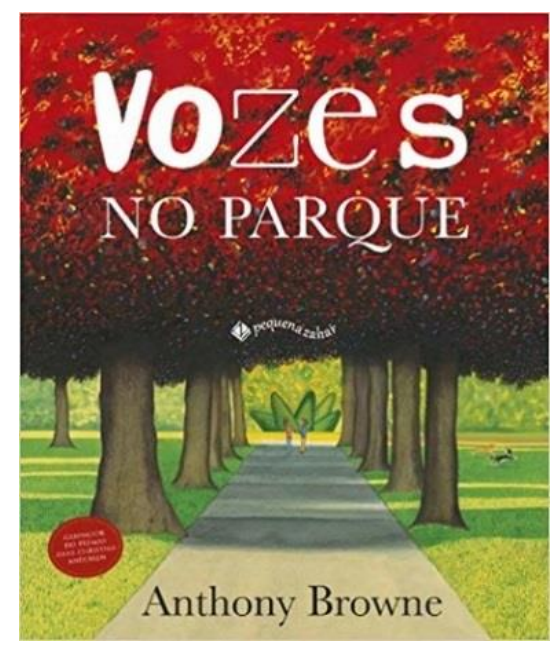

Fonte: Browne (2014).

Como outros livros-álbum de Browne, o autor desafia as capacidades imaginativas de seus leitores e lhes permite adentrar em um universo repleto de poesia. Essa é uma característica das obras de Browne: a presença de referências pictóricas, metamorfoses, elementos apresentados fora de sua função natural, assim como muitos detalhes que dão toques

\footnotetext{
${ }^{10}$ Editora Zahar, 2014.

${ }^{11}$ Estão traduzidas em Português King Kong, editora FTD, 1996; Gorila, editora Pequena Zahar, 2014; O túnel, editora Pequena Zahar, 2014; Na Floresta, editora Pequena Zahar, 2014; Tudo muda, editora Pequena Zahar, 2016; e Histórias de Willy, editora Pequena Zahar, 2017.
} 
poéticos e bem-humorados às cenas (GARRALÓN, 2014). Os protagonistas são gorilas, ocupando posições humanas (roupas, casas, comportamentos etc.), sem qualquer alusão a isto no texto verbal, seguindo uma tendência de outras obras do autor. Segundo Browne, em entrevista, a figura do gorila lembra seu próprio pai: um contraste entre a masculinidade, a força e a delicadeza (GARRALÓN, 2014).

No título da obra, já surge a utilização de um recurso estilístico que irá se expandir ao longo do livro - a palavra vozes está escrita com diferentes fontes, marcando a polifonia dos quatro personagens. É interessante também pontuar o quanto não só as vozes se modificam, mas o cenário e seus elementos, que se metamorfoseiam à medida que as relações entre os personagens também se modificam. Para Garralón (2014), as chaves visuais tornaram-se fundamentais no trabalho de Browne e chegam sem dificuldade nos leitores, que podem entender-se bem com ideias complexas e sofisticadas. As ilustrações são expressivas e provocadoras, com intensa exploração de intertextualidade - citações visuais diversas - e ambiguidade - o que revela mais de uma leitura possível. Em toda a obra do autor, o texto verbal e as imagens não se mesclam; por vezes, as imagens tomam toda a página; por vezes, aparecem dentro de molduras; e, por vezes, são pequenas. O estilo das ilustrações é realista, mas com elementos que parecem "fora do lugar", provocando um estranhamento no leitor. Estas características também estão presentes na obra em análise.

Em Vozes no parque, um mesmo episódio - o encontro de crianças e seus cachorros em um parque, levados por pai ou mãe - é narrado por vozes diferentes (Primeira voz, Segunda voz, Terceira voz, Quarta voz). Cada narrativa ocupa de seis a nove páginas do livro e sempre é feita em $1^{\text {a }}$ pessoa. Para Van der Linden, nesta obra, o autor mostra em alto grau o jogo de focalização, na medida em que "ao adotar o modelo da narrativa polifônica, [...] oferece sucessivamente quatro diferentes relatos de um mesmo acontecimento". E prossegue a autora: “Todas as vozes narrativas têm focalização interna: um personagem dá sua versão dos fatos. A esse relato subjetivo correspondem imagens que trazem, na maioria das vezes, um ponto de vista externo" (LINDEN, 2011, p. 133).

Em relação ao texto escrito e sua tradução para o Português, realizada por Clarice Duque Estrada, verifica-se o predomínio de um tom coloquial, com o uso de expressões correntes: "bobão", "legal", "pôr para cima", "traseiro", "chatonilda" etc., o que potencializa a unidade semântica da obra. O texto obedece a uma lógica de economia e simplicidade que contrasta com a complexidade da linguagem gráfica; ambos mantêm uma relação de complementaridade e de interdependência discursiva, característica dos livros ilustrados. 
Correndo o risco de, ao sintetizar os fatos, adotarmos um ou mais pontos-de-vista dos narradores-personagens, apresentamos brevemente o enredo. Um pai desempregado leva sua filha Manchinha e seu vira-lata Pedro para um passeio em um parque público, onde também vão passear, na mesma hora, uma mulher bem vestida e orgulhosa, com seu filho Carlos e seu cachorro Labrador Leopoldina. Inicialmente, os dois cachorros começam a correr juntos e, posteriormente, as crianças também brincam juntas, até os pais resolverem voltar do passeio. $\mathrm{O}$ final é aberto, sugerindo um gesto de amizade - que se prolongaria? - entre as duas crianças.

A primeira voz é a da mãe de Carlos: uma personagem com aspecto arrogante, bem trajada, que, além de seu filho Carlos, leva para passear Leopoldina, um cão labrador com pedigree. A casa de Carlos e sua mãe é imponente, em um cenário em que aparecem árvores de copa cheia na cor amarela, como se fosse outono. A mãe de Carlos narra os encontros dos cachorros e das crianças de um ponto-de-vista bem peculiar.

Figura $2-1^{\text {a }}$ voz: a mãe de Carlos

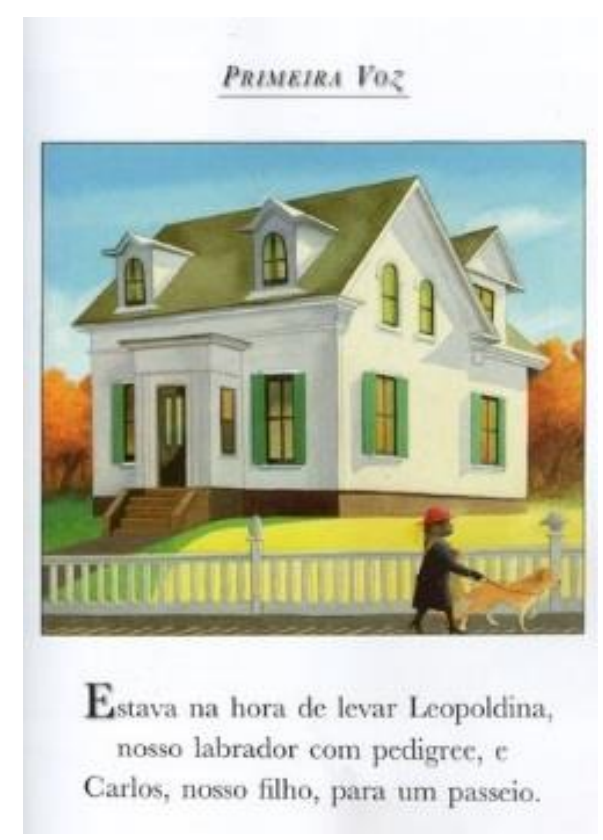

Fonte: Browne (2014).

A segunda voz pertence ao pai de Manchinha, retratado com roupas simples. O cenário do seu deslocamento rumo ao parque é urbano e, no trajeto, avulta uma cena de rua com elementos que denotam pobreza e tristeza: Papai Noel pedindo esmolas, árvores sem folhas, sujeira, rato, edifícios escuros. Ele está levando ao parque sua filha Manchinha e o cachorro 
deles, um vira-lata. Observa-se um personagem triste, desanimado, um desempregado à procura de emprego, conforme informa o próprio texto.

Figura $3-2^{\mathrm{a}}$ voz: o pai de Manchinha.

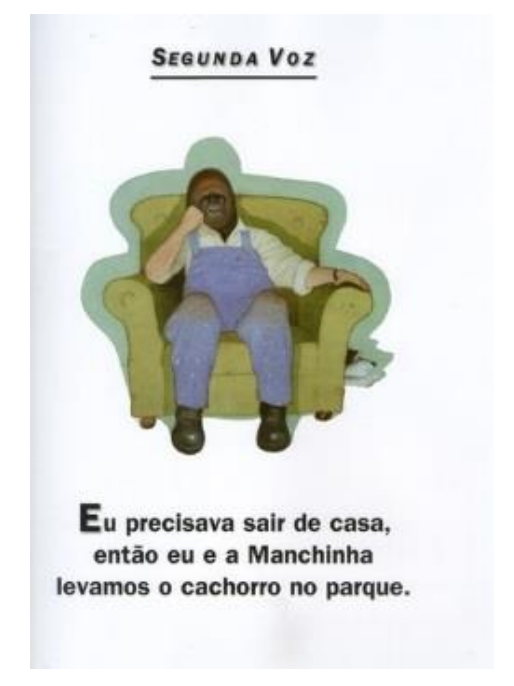

Fonte: Browne (2014).

Já a terceira voz é a de Carlos, um menino de classe média, bem trajado e bastante protegido pela mãe (a senhora da Primeira voz). As ilustrações caracterizam-no como alguém que se sente só e triste. Conforme a narrativa se desenvolve, os cenários se alteram - de maneira equivalente aos sentimentos de Carlos. O que parece ser tristeza e solidão floresce em alegria e diversão ao conhecer Manchinha; a brincadeira das crianças e cachorros parece colorir as páginas. De um cenário triste e solitário, passa-se a um cenário alegre e iluminado, que, aos poucos, volta a se apagar com um cenário de entardecer e o retorno à sua casa.

Figura 4 - $3^{\mathrm{a}}$ voz: o menino Carlos

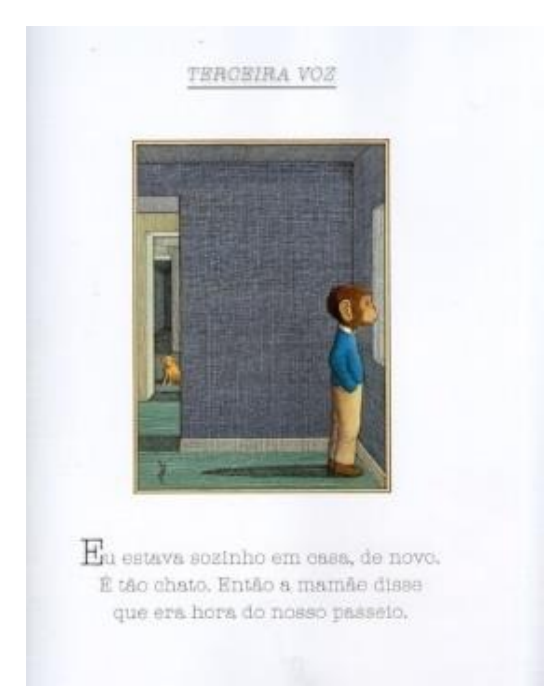

Fonte: Browne (2014). 
Por último, aparece a quarta voz, da menina Manchinha, apresentada como uma personagem alegre, cheia de energia, feliz por estar no parque com seu pai e seu cachorro Pedro. Vestida com roupas simples, parece ser bem cuidada. O cenário também é bem iluminado, com imagens de árvores com formato de frutas e flores, emoldurando as brincadeiras das crianças e cachorros. Manchinha parece ser espontânea e divertida.

Figura 5 - $4^{\mathrm{a}}$ voz: a menina Manchinha.

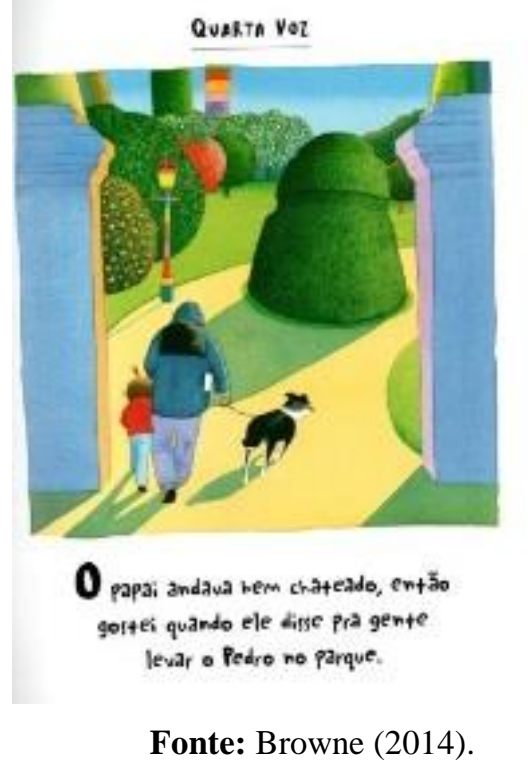

O passeio narrado apresenta o congraçamento das crianças e seus cachorros. Pai e mãe das crianças ficam distanciados. Em especial, a mãe (evidentemente abastada) demonstra desconforto e irritação com a proximidade entre os cachorros e as crianças. As temáticas de diferenças sociais, de geração e do mundo canino permeiam o texto de forma sutil. Os múltiplos detalhes e elementos "fora do lugar" das ilustrações da obra multiplicam as sugestões de significados da história. Há, assim, uma representação de um mundo real e, ao mesmo tempo, um afastamento desse mundo graças a um olhar onírico que permite, no manuseio da obra, mudar a perspectiva da leitura.

Trazemos a seguir algumas conversas mediadas dos alunos brasileiros e argentinos que revelam suas leituras da obra, e, por razões de organização do texto, as agrupamos em três eixos analíticos: a polifonia estrutural da obra e sua percepção pelos jovens leitores, a identificação das sugestões da obra sobre desigualdade social e os aspectos inusitados das ilustrações.

\section{As crianças leem e falam sobre suas leituras}

Eixo 1. A polifonia estrutural da obra e sua percepção pelos jovens leitores 
Nessa seção, centraremos nosso olhar em uma peculiaridade composicional da obra - o episódio central é narrado por vozes diferentes, com pontos-de-vista diferenciados, de personagens - narradores que foram ao parque em um mesmo momento -, e o modo como os alunos percebem esse elemento da narrativa na obra.

Para analisar a percepção desta polifonia estrutural pelos jovens leitores, os pesquisadores fizeram a seguinte questão desencadeadora inicial (ou variantes): São quatro histórias? Ou é uma história? O que vocês acham?? Qué quiere decir que tiene cuatro voces el libro?.

$\mathrm{Na}$ Escola 1, os alunos inicialmente apontam ser quatro histórias, considerando a subdivisão da obra em quatro partes, com marcas tipográficas distintas e títulos sucessivos, tanto que aludem a primeira voz, segunda voz, terceira voz e quarta voz. Vejamos o excerto ${ }^{12}$ :

P1: Deixa eu fazer uma pergunta antes... São quatro histórias? Ou é uma história? O que vocês acham?

[Várias vozes juntas]: Quatro! Uma!

P2: Quem acha que é uma?

A1(a): Quatro! Tem a primeira voz, a segunda voz, a terceira voz e a quarta voz...

Depois alguns alunos se atêm ao suporte, ao livro e sua materialidade.

A1(o): Mas isso não quer dizer nada, porque é uma história só!

P2: Como é que vocês sabem que é uma história só?

A2(o): Porque é só um livro!

P2: Não... mas, às vezes, pode ter mais do que uma história num livro...

Contudo, à medida que a conversa prosseguia, outras percepções apareciam, e, nessa conjunção de perspectivas sobre essa peculiaridade narrativa na obra, o consenso de ser uma "única" obra começa a aparecer.

P2: Como vocês sabem que é uma história só?

A1(o): Porque... Por causa que sempre quando eles vão se falar, eles sempre estão na mesma história... Tipo, eles foram se encontrar de novo no parque, eles estavam sempre lá no parque [...].

P1: Tá! O que mais que faz a gente ver que é uma história só?

A2(o): E os cachorros são os mesmos...

P1: E os cachorros também são os mesmos... E as pessoas são as mesmas...

A1(o): É! [Voz superposta - P1: Que mais?] As ruas são as mesmas...

Os excertos de fala evidenciam a relevância da mediação de leitura, em que a negociação de sentidos e sua permanente expansão estejam presentes. Observa-se que os alunos focalizam sua atenção prioritariamente nas imagens (cenários) para responder à questão, enfatizando que

\footnotetext{
${ }^{12} \mathrm{Na}$ transcrição dos excertos da pesquisa brasileira, obedecemos às seguintes convenções. Usamos P1 e P2 para as pesquisadoras, quando há mais de uma fala na cena. Por questões de sigilo, os alunos são identificados apenas por números crescentes em cada excerto, identificando-se seu gênero por (o) - menino e (a) menina. Quando pretendemos pôr em relevo alguma fala, utilizamos itálico.
} 
"sempre quando eles vão se falar, eles sempre estão na mesma história...", "eles estavam sempre lá no parque”, "E os cachorros são os mesmos... As ruas são as mesmas...".

Vamos percebendo também que é na complementação e confronto de ideias uns com os outros, que os alunos vão construindo sentido para a pergunta feita. Especificamente sobre a leitura de imagens, Ramos e Panozzo (2013, p. 31) salientam como elementos relevantes "o olhar curioso, atento, perscrutador, que se desenvolve pelo desafio e se amplia nas descobertas gradativas".

Na Escola 2, a focalização na imagem também ocorre no início da interação com o livro, contudo com outras inferências. Ao conversar sobre o título da obra, os alunos fazem algumas considerações das vozes como algo que assusta, dá medo, algo como "escuta de vozes". No entanto, após a leitura e as mediações realizadas durante a mesma, os alunos associam a indicação das quatro vozes na obra com outras práticas sociais, como o uso do "shampoo dois em um". Vejamos o excerto:

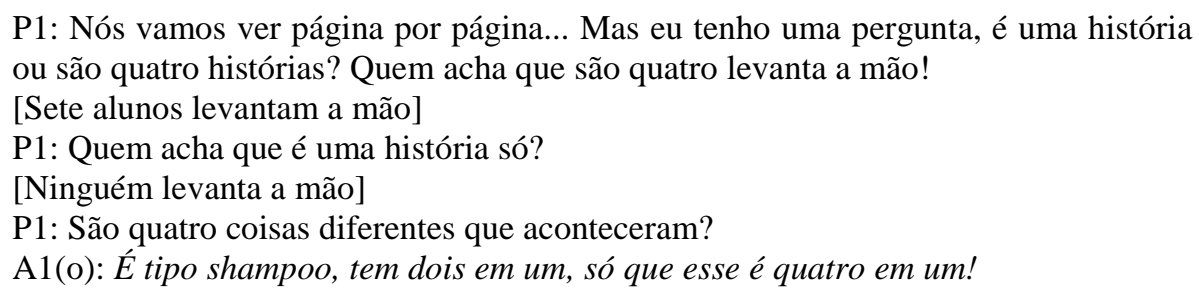

No caso, "É tipo shampoo, tem dois em um só que esse é quatro em um!" emerge do universo cultural desse grupo de alunos, talvez menos conhecido pelo grupo de alunos da Escola 1, devido às condições socioeconômicas dos mesmos.

Depois, ao ser retomada a questão, apontam, ainda:

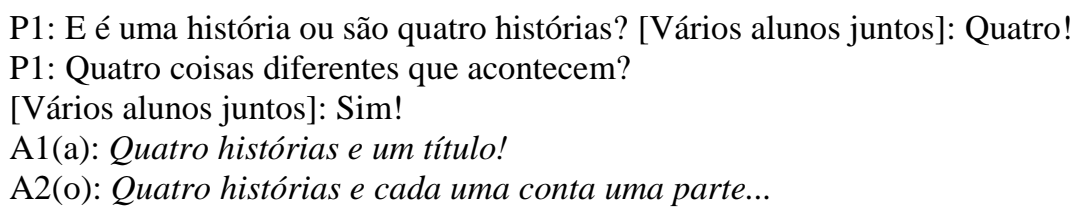

Observa-se que, diferentemente do outro grupo, esta turma tem mais dificuldades para capturar a arquitetura narrativa do livro, mesmo quando a mediadora reformula a provocação. É evidente que os alunos percebem a interrelação entre as narrativas ("cada uma conta uma parte"), mas a materialidade do suporte parece ter tido um peso maior em suas respostas, além da dificuldade com as questões de sequência versus simultaneidade do tempo narrado.

De qualquer forma, observamos, nessas sessões de mediação de leitura, que a interlocução entre leitores, pesquisadores e a obra favoreceu que os sentidos circulassem mais livremente, já 
que os alunos se engajaram na discussão, levantando hipóteses sobre as imagens da obra e suas experiências pessoais, travando diálogos até chegar em um certo "consenso" sobre as "vozes" e a obra apreciada.

Podemos, agora, voltar nosso olhar para a pesquisa argentina referida em "Sobre líneas", considerando as respostas dos alunos de uma das escolas investigadas, qual seja EPM, para a questão: Qué quiere decir que tiene cuatro voces el libro? descritas no excerto abaixo ${ }^{13}$.

\footnotetext{
MCT: - Qué quiere decir que tiene cuatro voces el libro?

Tatiana: - Que tiene cuatro temas.

MCT: - Cuatro temas, muy bien. Um tema es la mamá y el chico, hay algún outro que quieran nombrar?

María: - De la ninã y el papá.

MCT: - Muy bien, outra historia de la ninã y el papá. Faltarían otros temas.

Brenda: La historia de la chica y el chico [...].

MCT: - Ahí está, la relación del ninô y la ninã.

Brenda: - Que se conocen y se hacen amigos.

María: - También que a la señora no le gusta que al perrito le huelan el...

[Se interrumpe; parece no animarse a decir la palavra que piensa].

MCT: - [menciono término con naturalidad]: - El trasero, claro, esa señora!
}

É interessante observar que também este grupo percebeu a polifonia narrativa; no entanto, as crianças justificaram a presença das vozes não pelos enunciadores (mãe, pai, menino, menina), mas pela marcação de temas em cada voz. A pesquisadora, (MCT), frente à alusão das crianças ao "tema", já situa o primeiro: "la mamá y el chico", o que deflagra a resposta das crianças sobre os outros temas (que foram enunciados pelas diferentes vozes): la ninã y el papá; La história de la chica y el chico [...] la la señora no le gusta que al perrito.... As vozes, apesar de marcadas no texto verbal como primeira, segunda, terceira e quarta voz, estão articuladas a uma proposta visual que enfatiza os acontecimentos, levando os alunos a mesclarem os mesmos com os tempos e espaço dos personagens que os narram. Já no relato da pesquisa argentina referente à segunda escola, EEJB, não está presente uma discussão específica sobre a questão das vozes. Apenas na transcrição do diálogo motivado pela pergunta da pesquisadora sobre o que havia chamado a atenção no livro, ressalta uma resposta de um aluno, que, entretanto, não é retomada (ou cuja discussão não foi inserida no livro):

Gregorio: A mí me gustó que había cosas escondidas y que está rebueno el cuento [...] porque es como uma historia vista de distintas vistas.

Vê-se, assim, que os alunos das Escolas 1 e 2, do Brasil, e os alunos argentinos encontram em uma única narrativa quatro narrativas diferentes. Ao analisar o livro ilustrado nas sessões

\footnotetext{
${ }^{13}$ Para manter a fidelidade do tom coloquial nos diálogos das crianças argentinas com a pesquisadora, mantemos os excertos com o uso original da língua, em espanhol.
} 
de leitura mediada, os alunos leitores são desafiados pela interação entre as linguagens verbal e a gráfica, que estimulam o imaginário e propõem enigmas, fazendo-os mergulhar no grande universo de sensibilidade e de afetos da obra de Anthony Browne.

\section{Eixo 2. A identificação das sugestões da obra sobre desigualdade social.}

Iniciamos este eixo, apontando que, nas conversas com os alunos brasileiros e argentinos, a percepção sobre a desigualdade social sugerida pelo autor como questão de fundo do livro, através da caracterização e marcação de diferenças socioeconômicas entre os personagens e seus ambientes, foi um ponto em comum identificado na recepção das crianças à obra.

É pertinente salientar que as crianças das duas escolas públicas de Porto Alegre envolvidas na pesquisa pertencem a famílias de baixa renda, de nível econômico médio baixo e baixo. De maneira específica, a escola municipal (Escola 1) fica na zona leste da capital gaúcha, na periferia urbana da cidade, e, conforme pesquisa de Mello (2006), a partir do Censo - IBGE (Brasil, 2000), tal zona abarca o segundo maior percentual de população negra da capital e o maior percentual de pessoas com renda de até dois salários-mínimos, caracterizando, assim, uma população de baixa renda. Já a Escola 2, situada em bairro mais central, acolhe tanto crianças de uma "vila" próxima quanto de famílias de classe média baixa.

Vejamos as falas das crianças brasileiras sobre o tema. Na Escola 1, logo após o término da leitura conjunta, se inicia o diálogo:

\footnotetext{
P1: Quem tá com a mão levantada? Quem é que quer falar da história? Fala! A1(o): Porque a mãe dele não gostava que... Que ele se misturava com outros que tem menos dinheiro...

P1: Porque a mãe dele não gostava que ele ficava com outros que tem menos dinheiro do que ele? É isso que apareceu né?

$\mathrm{A} 1(\mathrm{o})$ : Ela é arrogante?

P1: Ela é arrogante, é uma boa explicação!

[Voz superposta - A2: Ignorante!].

P1: Ignorante... Tá! O que mais que chamou a atenção...

A1(o): Ela é esnobe!

P1: Esnobe! Ela é esnobe! Muito bem! Que que tu queres dizer?
}

A captura e verbalização do principal conflito da narrativa - os obstáculos à amizade e convívio entre duas pessoas de classes diferentes caracterizando o preconceito social da senhora rica - foi imediata à leitura conjunta, nesta escola, e tem continuidade na exploração página a página das ilustrações. Então, as atenções se voltaram para a descrição da primeira voz (Figura 2), na página em que se encontram os personagens Carlos, sua mãe e a cachorra Leopoldina: 
P2: Vamos começar com essa imagem, primeira voz, essa página. O que tem nessa página aqui?

[Vários alunos juntos]: A casa!

A1(o): O Carlos!

P2: Mas qualquer casa? A minha casa?

A1(o): A casa do Carlos!

P2: Ah, a do Carlos! Mas como você sabe?

A2: É uma mansão...

A1(o): Porque eles estão na frente!

P2: Uma mansão... Eles estão na frente...

A3(a): São ricos!

P2: São ricos... É a esnobe né? O Lucas disse que ela é esnobe! Então, é a casa

dela... Que mais a gente vê?

A4: Exibida, sora...

A5(o): A raça do cachorro...

No primeiro momento, o foco de atenção das crianças foi identificar e caracterizar os personagens e o cenário da ilustração. Assim, a casa é de Carlos, pois ele e sua mãe estão na frente, e ela é uma "mansão”. Os personagens são considerados ricos, e a mãe de Carlos, de maneira pontual, é novamente descrita como "exibida" e "esnobe". Outro ponto que chamou a atenção dos alunos contribuindo para a conotação de riqueza da família foi a raça do cachorro - um cão de pedigree, diferentemente da cachorra de Manchinha, que é um vira-lata. Os contrastes diversos entre os dois núcleos familiares são citados pelos jovens leitores, começando a compor uma caracterização mais completa.

Na página seguinte (Figura 6), a mãe de Carlos divide a cena com o pai de Manchinha, que ocupa o canto esquerdo da imagem, em um espaço bem menor do que o da mãe de Carlos, que se encontra em pé, e o ignora à procura do filho. O pai de Manchinha, em mais uma evidência das diferenças sociais entre os personagens, veste roupas sujas e se mostra concentrado no jornal, à procura de emprego. Não há relação, contato ou sinal de aproximação entre eles. Há, sim, uma aparente divisão, assim identificada pelas crianças:

P1: Vamos olhar de novo, por que será que tem um poste atravessado? A1(o): Pra dividir os dois, porque a imagem dela tem que ser mais forte do que a dele...

P2: Por que é que a imagem dela seria mais forte do que a dele?

A2(a): Porque ela tem mais dinheiro...

[Várias vozes juntas]

P2: Porque ela é mais o quê?

A3(a): Bonita! 
Figura 6 - Mãe de Carlos e pai de Manchinha na praça.

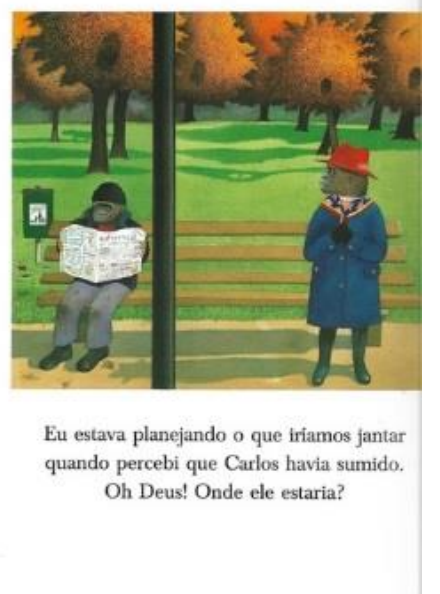

Fonte: Browne (2014).

Interessante observar como as crianças interpretam, na ilustração, o poste como uma maneira visual de separar os personagens na cena, no que seria a identificação de uma 'metáfora visual' de Browne. Assim, apontam que a imagem dela deve ser mais forte do que a dele, associando a força da personagem com o tamanho do espaço ocupado na página e com o fato de que tem mais dinheiro e seria 'mais bonita' do que o pai de Manchinha. Mais uma vez, a ilustração vale-se de vários elementos para realçar a questão de fundo da desigualdade social, a invisibilidade do pai de Manchinha e a dificuldade de relacionamento entre os personagens.

Já na Escola 2, as conversas focalizaram uma perspectiva mais detida sobre a personagem rica da história e sua aversão à Manchinha e, consequentemente, a pessoas que não fazem parte do mesmo meio social por terem menor poder aquisitivo. A percepção das crianças a respeito da mãe de Carlos se deu da seguinte maneira, quando questionadas a respeito da personagem:

\footnotetext{
P1: Pareceu que ela é uma pessoa assim alegre, feliz? [vários alunos juntos]: Não!

A1(a): Ela é infeliz, ela não gosta de pessoas que seja como a gente, ela gosta de pessoas ricas...

A2(a): Ela é tipo uma patricinha...

A3(o): Ela não gosta da Manchinha por causa do pai dela...

A4(a): E também não gosta da Manchinha porque ela parece uma pessoa diferente, alegre...

A5(a): Ela só gosta de pessoa rica, só do tipo dela...

A6(a): Ela não gosta de gente pobre porque quem pode ser amigo do filho dela, tem que ser pessoas ricas...
}

Inicialmente, a mãe de Carlos é rotulada com adjetivos e expressões como "infeliz" e "patricinha", porém a visão crítica dos leitores vai além: eles entendem que a personagem não gosta de Manchinha por causa de seu pai (que é o oposto da figura da mãe) e também porque Manchinha parece uma pessoa alegre e, portanto, bastante diferente do que a mãe-gorila 
demonstra ser. Contudo, o que mais chama atenção nessa conversa é o comentário de um dos alunos ao dizer que "ela não gosta de pessoas que sejam como a gente, ela gosta de pessoas ricas", e quando outro constata que "Ela não gosta de gente pobre porque quem pode ser amigo do filho dela, tem que ser pessoas ricas". Desse modo, ao estabelecerem verbalmente a oposição nós (a gente) / eles (o tipo dela), as crianças se identificam com Manchinha, a personagem economicamente desfavorecida da história: elas se entendem também nessa posição, a partir da sua realidade e de seu contexto de vida. As associações da narrativa com suas experiências de vida remetem ao que Gregorin Filho (2009) enfatiza sobre a figura do leitor no processo de compreensão dos textos: "O leitor no momento de seu exercício de entender e interpretar os textos que o rodeiam, ativa a sua memória, relaciona fatos e experiências, entra em conflito com valores, coloca vários textos em diálogo". (GREGORIN FILHO, 2009, p. 44-45).

Por mais que residam em países diferentes, em contextos de vida diversos, as percepções das crianças nas escolas municipais de Buenos Aires (Argentina) são próximas às das crianças brasileiras. Vejamos: no primeiro diálogo, ocorrido na EPM, a menina Tatiana explica à pesquisadora Thomson os motivos de a mãe de Carlos não querer que se ele junte para brincar com a menina:

$\mathrm{MCT}^{14}$ : - Muy interessante, que te hace decir que es muy interessante?

Tatiana - Porque la mamá no quiere que se junte com uma nena que se veía un poco mal vestida[...]. Que la madre no quiere que esté el hijo com la nena porque es diferente.

Quando, em seguida, a pesquisadora pede que a aluna explique melhor a diferença referida ("es diferente"), a justificativa veio através da alusão à roupa dos personagens. Por sua vez, a aluna Judith alerta que a mãe de Carlos não queria a aproximação de Manchinha, pois ela (a mãe) é de outra classe, é uma senhora milionária.

\footnotetext{
MCT: - Ajá, y decime, Tatiana, em qué sentido te parece que es diferente?

Tatiana - Como que el hijo, sí, esto también [senãla imagem y ejemplifica], la forma de vestir. Se viste así no más la nena, y el hijo se viste así todo bien vestidito[...].

Judith: - La mamá no queria que se junte com la nena porque es de outra clase la nena...

MCT: - De qué classe te parece a vos que es? [Ninã calla; re-pregunto]. Bueno, de qué classe te parece que es la señora?

Judith: - La senõra es millonaria.
}

Segue-se uma conversa sobre "personas millionárias", inclusive com uma menção de um aluno a outra característica dos "milionários": "Y también tienen el carácter de las personas

\footnotetext{
${ }^{14}$ A sigla "MCT" se refere às iniciais do nome da pesquisadora María Cristina Thomson.
} 
milionárias [...]", "Algunos milionários como esa señora que no les gusta ver, como que no... No le tiene compreensión a los niños de la calle" (THOMSON, 2016, p. 84).

Já na outra escola municipal argentina, EEJB, possivelmente com alunos de melhor condição econômica, houve uma única vez durante a discussão de Vozes no parque em que as crianças mencionaram as diferenças socioeconômicas entre as famílias protagonistas. A conversa girou em torno da mesma imagem presente na Figura 6 - a que marca a separação e a distância entre o pai de Manchinha e a mãe de Carlos através de um poste atravessado.

\footnotetext{
MCT - Porque está sin trabajo y no tiene plata. [El niño por el momento calla; más tarde vuelve sobre el mismo tema].

MCT [a Lucas]: - Algo nuevo querés agregar?

Lucas: - Yo quiero decir que esta imagem [...] el dia está feo, el mono está feo, y la mona está linda. O sea que la mona se viste bien y, como te dije hace um rato, el mono se viste... No tiene mucha plata, entonces se viste mal.
}

No entendimento de Lucas, o macaco (o pai de Manchinha) é feio (se veste mal) e a macaca (mãe de Carlos) está linda, porque se veste bem e tem condições para isso. Segundo Thomson (2016), a percepção de Lucas se deu no plano das diferenças entre as pessoas desempregadas e aquelas que possuem uma posição econômica estabelecida, a partir da ambientação das ruas e da vestimenta dos personagens.

A conclusão da autora argentina sobre a leitura da obra feita pelos alunos argentinos poderia ser generalizada também para as turmas brasileiras. Vejamos:

\begin{abstract}
Pelos comentários das crianças, concluo que a leitura cuidadosa das imagens visuais, juntamente com os breves textos, quase imediatamente as leva a refletir sobre a abordagem ética subjacente ao tema da história: as desigualdades socioeconômicas como causa do confronto entre diferentes classes sociais. [...] Deduzo que a insistência no assunto - trazido recorrentemente durante a sessão - se deve ao fato de que, possivelmente, elas encontrem na história o reflexo de experiências que observam ou experimentam em sua vida cotidiana. (Thomson, 2016, p.85-86, tradução nossa) ${ }^{15}$.
\end{abstract}

\title{
Eixo 3. Leitura de imagens
}

Frente à experiência de tomar contato com a visualidade do livro Vozes no parque, tanto crianças brasileiras quanto argentinas mostraram-se sensíveis aos aspectos surrealistas e à presença de elementos 'estranhos' nas ilustrações. Motivadas pelas pesquisadoras (brasileiras

\footnotetext{
${ }^{15}$ No original: "Por los comentários de los niños concluyo que la lectura atenta de las imágenes visuales junto com los breves textos los remite casi de imediato a reflexionar sobre el planteo ético que subyace em el tema del cuento: las desigualdades socioeconómicas como causa del enfrentamento entre distintas clases sociales. [...] Infiero que su insistência sobre el tema - lo traene a colación recorrentemente durante la sesión - se deba a que, posiblemente encuentren em la historia el reflejo de experiências que observan o experimentan em su vida cotidiana".
} 
e argentina) a falarem sobre o que viam nas imagens ou nelas lhes chamava atenção, se manifestaram frequentemente com entusiasmo e assombro.

Pensemos, em primeiro lugar, na questão da antropomorfização dos gorilas, processo que não só abrange os quatro protagonistas, como alguns personagens "figurantes": o mendigo que pede esmola (e, páginas após, dança), vestido de Papai Noel e as estátuas do chafariz. A presença de personagens gorilas no lugar de humanos, com uma antropomorfização que atinge ações, falas, atitudes, roupas, ambientes, atraiu a atenção dos quatro grupos de leitores (brasileiros e argentinos), que passavam do espanto inicial à identificação do mundo narrado com o mundo humano. A utilização de personagens gorilas antropomorfizados ganha mais força, na medida em que tal dimensão jamais é mencionada no texto verbal, assim como a grande maioria dos elementos extraordinários, surrealistas, 'oníricos', (cf. GARRALÓN, 2014) das ilustrações do autor.

Vejamos como uma turma de crianças brasileiras, da Escola 2, responde ao questionamento sobre a visualização da figura que abre a Primeira voz (Figura 2):

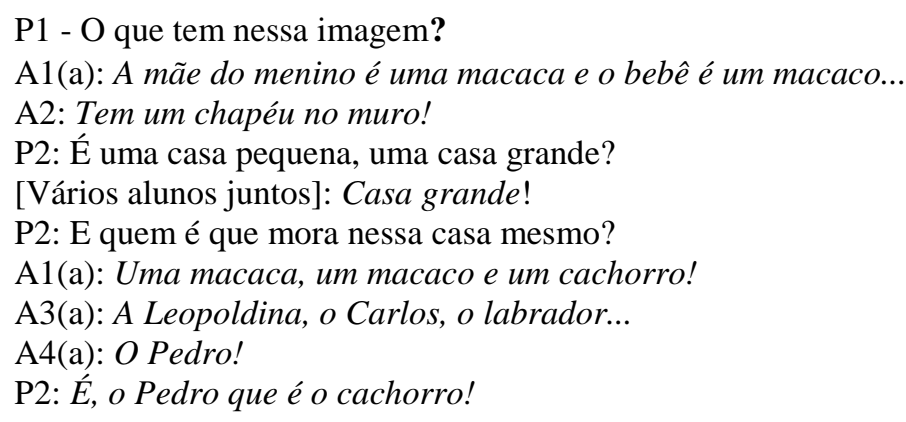

Para além da identificação inicial dos elementos e de detalhes, as crianças assumem com "naturalidade" a caracterização visual dos protagonistas como animais, o que se pode constatar nas conversas posteriores, em que, nos quatro grupos de leitores, pôde se observar a utilização de expressões adequadas a seres humanos, para falar de seu enredo: "la señora", "la madre", "la nena", "otras personas", “chicos"; “a mulher", "as pessoas", "o menino". A manifestação de um aluno da escola argentina EEJB, em resposta à provocação da pesquisadora sobre o que havia surpreendido no aluno, sintetiza tal postura. Juan Elias: “A mi me surprendió que los personajes fueran monos, porque si hubieran sido humanos, la historia no tendría por qué haber cambiado de ninguna manera".

Um notável exemplo de ilustração cuja "excentricidade" chamou a atenção tanto das crianças argentinas como as brasileiras - e que está relacionada com a ambiguidade do significado dos personagens gorilas "humanos" - consiste na representação do pai de 
Manchinha, conforme apresentado na Figura 3. Espontaneamente, as crianças manifestaramse:

\author{
Escola argentina (EPM): \\ Camila: - También que acá en esta imagen noté que tiene como cuerpo de humano y \\ cabeza de animal. \\ MCT: - Muy bien. \\ Camila [mientras señala la figura del padre de Mancha]: - Las manos son de uma \\ persona y el cuerpo especial, o se ala cabeza.
}

\title{
Escola argentina (EEJB)
}

Ariel: - Yo lo que no entendi es que el mono, em la segunda voz, cuando empeza a hablar que tiene cara de mono y manos de hombre.

\section{Escola 1 (brasileira)}

A1 (a): Sora, sora, sora! Mas o braço dele é branco e a cabeça dele é preta! P2: O braço dele é branco e a cabeça dele é preta... [voz superposta - A5(o): Pior né?] É verdade! Nós também tínhamos notado isso.

A2 (a): Ele é meio metade humano e meio metade gorila!

P2: Metade humano e metade gorila...

\section{Escola 2 (brasileira)}

A1(o): Ele tem cara de macaco e braços de humano...

Registre-se que, na $2^{\mathrm{a}}$ escola argentina, EEJB, esta questão gerou contestações: um aluno procurou argumentar sobre a peculiaridade das mãos dos gorilas, o que mostraria a coerência da representação do animal. Isto provocou longas discussões.

Outros elementos "extraordinários" se fazem presentes nas ilustrações de Vozes no parque, não referidos no texto verbal. É o caso, por exemplo, das múltiplas imagens de árvores que se espalham pelas páginas: são árvores que simulam cabeças, inclinadas a ponto de sugerirem queda iminente, pegando fogo (ver Figura 7), com copas folhosas ou apenas galhos nus, floridas, com copas de cores e formas diversas (macacos, chapéus, frutas, rabos de animais); por este motivo, chamam a atenção dos pequenos leitores de diversas origens, como no caso das crianças argentinas da EPM.

Camila: - También yo observé que hay árboles en forma de frutas, así [muestra imagen], o sí no hay árboles de distintos colores, como rojo y distintos colores, así [muestra imágen] y también...

Ariel: - Los árboles se parecen como forma de monos.

María : - También noté yo que hay árboles con fuego, o como caminos com hojas e todo así, eso quiere decir algo [....]

Alan: - Acá hay árboles que también tienen forma de sombrero 
Figura 7 - Árvores em movimento.

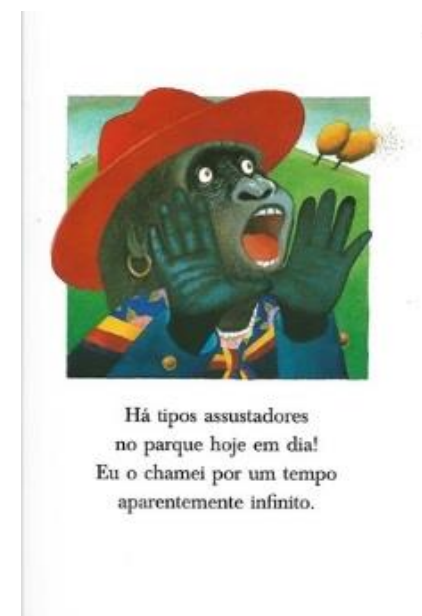

Fonte: Browne (2014).

Também na escola EEJB, várias foram as reações a tais elementos. Apenas exemplificamos:

Ariel: - Lo que me surpreendió era que, a ver... [muestra image] Este árbol prendidofuego! Está buenísimo, frutilla.

Facundo: - A mí me surpreendió mucho que los árboles tengan forma de frutas, me pareció muy creativo. Tenían forma de pera, manzana.

Já as crianças brasileiras reagem de forma individual ou quase em uníssono a tais imagens: "Uma árvore caindo" (Escola 2); "A árvore tá caindo" (Escola 1); "Tem árvores com rosto!" (Escola 2), frente à imagem aqui reproduzida como Figura 6, que suscita, na Escola 1, um diálogo mais desenvolvido e entusiástico, frequentemente com o uso de dêiticos (“ali”) e o gesto de apontar no livro:

\footnotetext{
A5(o): As árvores também estão gritando aí! P1: As árvores estão fazendo o quê? A5(o): Gritando, assim ó! Ohh! P2: Olhem as árvores... Olhem as árvores! A5(o): Ali! Ali! Olha as bocas delas, ó!
}

E a árvore que parece cortada pela corrida dos cachorros amigos, assim como mudanças na aparência das mesmas árvores nas cenas de rua da Segunda Voz são imagens também notadas e comentadas pelas crianças. Garralón (2014, p. 14) observou, a respeito, especificamente das árvores em forma de frutas, que elas "dão uma dimensão onírica do momento e convidam o leitor a manter alerta visual durante a sua leitura visual". Efetivamente, de forma rápida, a partir da primeira página, os jovens leitores adotam uma atitude quase detetivesca de procura dos elementos inusitados nas ilustrações, mantendo um "alerta visual". 
Isto parece vir ao encontro do pensamento expresso pelo autor; afirma ele: "Gosto que haja algo nas ilustrações que não seja reconhecido numa primeira vez, de modo que a criança possa retornar e descobrir coisas nos desenhos. Esta técnica torna o livro algo que poder-se-ia querer voltar" (GARRALÓN, 2014, p. 13), quando tenta explicar o porquê dos elementos que aparecem em seus desenhos. Juan Elias, aluno da segunda escola argentina (EEJB), a uma provocação da pesquisadora, observa de forma perspicaz sobre o autor: "[...] tiene ideas curiosas. Por ejemplo, el hecho de esconder cosas ocultas en las distintas páginas".

Outro elemento central no código imagético instaurado por Browne em Vozes no Parque é o chapéu (ou sua forma característica) da mãe de Carlos; ele aparece, com sua cor vermelha, tanto na folha de rosto, quanto na contracapa. Já na primeira página, (Figura 2), a presença da forma do chapéu na pilastra do muro da casa, ainda que constituindo pequeno detalhe, chama a atenção de um leitor. Árvore com copa em forma de chapéu, postes de luminária, assim como nuvens com este formato, reaparecem na segunda ilustração da Terceira Voz. Um chapéu ou a reprodução de seu formato característico reaparece em mais duas páginas, e sua presença sempre é identificada por um ou mais alunos. Vejamos os comentários das crianças brasileiras da Escola 1 frente à segunda ilustração da terceira voz:

A1(a): A árvore parece um chapéu...

A1(a): [inint]... E o céu fica azul e tem chapéu...

P1: Olha só, que interessante, a árvore parece chapéu, ela falou e aqui...

A1(a): As nuvens e as lâmpadas tem formato de chapéu também...

P1: As nuvens tem formato de chapéu também...

[Várias vozes juntas, inint]

A2(a): Sora, a sombra aqui...

P1: A sombra de quem?

A3(o): É da mãe do Carlos!

P1: Ela usa chapéu?

A2(o): Usa!

P1: Agora, presta atenção na pergunta, por que será que tem chapéu na imagem, em todo lugar?

A4(o): Por causa da mãe dele!

P1: Por que, por causa da mãe dele?

A5: Porque ela usa chapéu!

P1: Porque a mãe dele usa chapéu...

A6(a): Porque tá tudo triste...

A reprodução do fragmento de interação acima nos serve de mote para outro tópico acerca da leitura de imagens do livro. Para além da simples menção aos elementos surrealistas da obra de Browne, observam-se, em respostas das crianças dos dois países, tentativas de atribuição de significado, às vezes provocadas pela mediação, às vezes não. Assim, no primeiro excerto acima, a observação de María se alinha a tal sinalização: "e todo así, eso quiere decir algo". Já da transcrição das sessões de leitura das crianças brasileiras, podemos pinçar vários excertos 
em que, principalmente questionados pela mediadora, os/as alunos ensaiam algumas leituras interpretativas, nem sempre aceitas por todos os leitores. Assim, em relação às figuras 6 e a da página seguinte, o movimento das árvores é mote para uma tentativa de explicação.

\section{Escola 2:}

A1(a): Tem uma árvore que vai cair... Duas...

P1: Tá, vamos pensar sobre isso, ela tá gritando, pra quem que ela tá gritando? A2: Pro filho dela!

A3(a): [inint]... Quando ela tá gritando as árvores voam, vai pro lado aqui ó!

P1: Por que que a árvore tá voando, indo pro lado?

A3(a): Porque o grito dela é forte...

P1: Porque o grito dela é forte! Olha só...

A4(o): Tá, mas tão forte pra fazer a árvore voar?

P1: É uma imagem, né?

Mesmo quando não se trata de um elemento que foge ao realismo restrito, mas sim pertence ao nível da composição da figura, leitores infantis ensaiam interpretações, como a que já foi explorada em relação à Figura 6, na qual um poste separa dois mundos: o do pai de Manchinha e o da mãe de Carlos. Em relação à ilustração aqui reproduzida como Figura 8 (Terceira voz), um grupo de crianças percebeu e interpretou uma metáfora imagética; os dois cachorros, lado a lado, correm e os rabos dos dois estão trocados, o que se torna visível por causa das pelagens diversas (algo que as pesquisadoras não tinham percebido anteriormente). Vejamos partes da conversa:

Figura 8-Cachorros correm pelo parque.

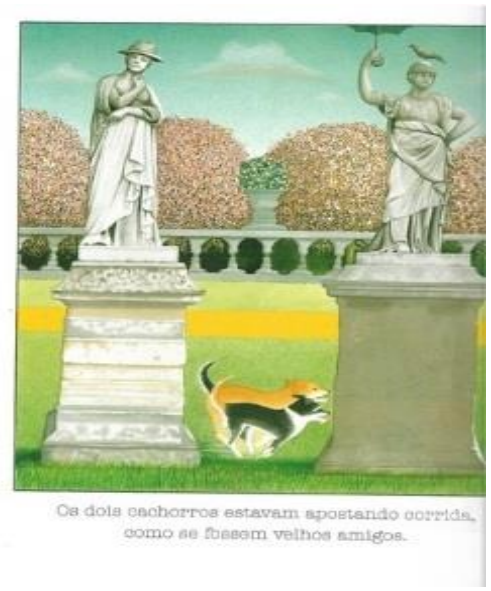

Fonte: Browne (2014).

A1(a): Os rabos são diferentes!

P1: O rabo dos cachorros!

P2: Eu não tinha visto isso! O rabo dos cachorros tá trocado!

A2(o): Eles estão em um laço... 
P1: Olha só que interessante, o rabo da Leopoldina tá nele...

P1: Por que será que ele desenhou assim?

A3(o): Pra significar que eles têm... Coisa... Pra significar que eles estão ligados, juntos...

P2: Pra significar que eles estão ligados!

Outros exemplos poderiam ser pinçados das leituras e discussões feitas, mas estes nos parecem suficientes para apontar uma atitude de busca de sentido nos elementos imagéticos inusitados da obra. Semelhante atitude foi observada nas crianças argentinas, como registra Thompson (2016, p. 82), ao afirmar que os alunos "infieren, asimismo, que los efectos inusuales y cambiantes que detectan en el paisaje esconden significados metafóricos”.

Outra dimensão digna de ser apontada na análise diz respeito à conexão entre a leitura de imagens singulares e a totalidade da obra; relembre-se que, no caso da pesquisa brasileira, foi feita inicialmente uma leitura conjunta do texto verbal do livro - com alunos seguindo a leitura em exemplares da obra - para, depois, ser feita a exploração, página a página, das ilustrações. Assim, frente à Figura 6, já analisada, a turma da Escola 2 assim se manifesta:

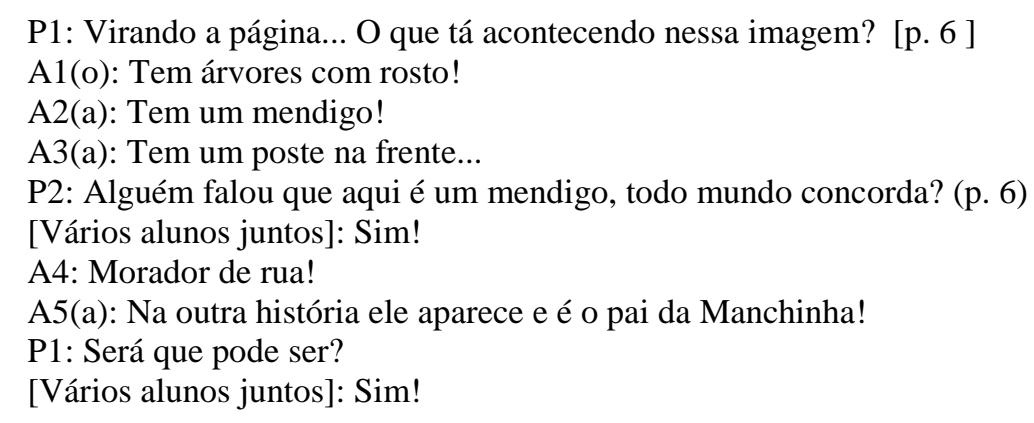

A memória da leitura anterior permitiu a uma menina corrigir a informação sobre o protagonista que os colegas caracterizaram de forma genérica (mendigo...), apesar de sua imagem ser coincidente com sua aparição páginas após. Este excerto também apontou a relevância de uma discussão partilhada, em que equívocos evidentes podem ser apontados pelos próprios colegas. A consistência do projeto visual da obra propiciou também comparações entre duas imagens da Segunda Voz que tomam toda a página e retratam um mesmo cenário de rua, pelo qual, primeiramente, o pai de Manchinha, a menina e o cachorro Pedro se dirigem ao parque e, posteriormente, quando voltam dele. 
Figura 9 - A ida ao parque.

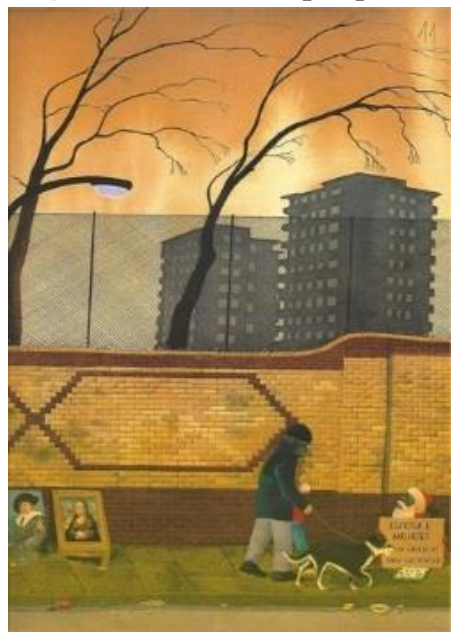

Fonte: Browne (2014).
Figura 10 - A volta para casa.

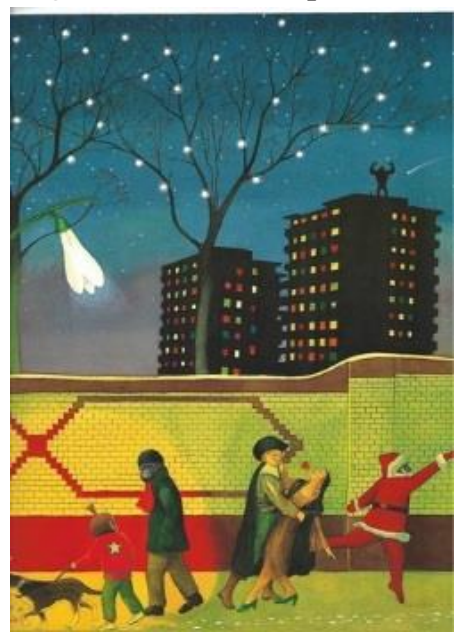

Fonte: Browne (2014).

As duas turmas de crianças brasileiras demonstram alegria em comparar as duas cenas, apontando semelhanças e diferenças. Vejamos algumas passagens apenas da longa transcrição da conversa da turma na Escola 1:

P1: Aqui ó! Ela [se refere a uma aluna] tá dizendo, é o mesmo lugar, [voz superposta - A1: Só que mais colorido!]

P1: Só que nessa página tá tudo bonito e colorido porque a pessoa, o quê?

A2(a): É rica!

P1: É rica, aqui, tá feliz! Aqui as pessoas estão tristes, tudo parece feio, é isso? É o mesmo lugar, não é? O que que tem de diferente?

A3(a): Ô sora, o Papai Noel estava pedindo esmola, agora ele tá feliz...

P1: Olha só! O carinha que tava pedindo esmola aqui, nessa outra imagem.

A4(a): Tá dançando...Tá feliz! [...]

A5(a): Ô sora, as flores estão crescendo agora...

A6(a): Ô sora, tem... Agora ele tá saindo feliz e limpo!

[...] A7(o): O muro tá sem caco de vidro agora!

A8: E ali tem um macaco que no outro não tem!

A9(o): Tá sem grade!

P1: Tá e as janelas? Quem que ia falar das janelas? Fala!

A10(a): Tem janelas em formato de estrela, de coração e quadradinha...

P1: Vocês viram? Colorido e é em formato de estrela, coração, quadrinho...

A10(a): E é todas coloridas também!

A9: E ela tá dançando e tem uma rosa...

P1: Tem uma rosa na boca! E o que será que isso quer dizer?

A8(a): Nessa página tem uma lâmpada que é assim [...]

A11(o): O Papai Noel...

P1: Tem o Papai Noel dançando aqui...

A8(a): Uma estrela cadente!

A10(a): A Monalisa tá com uma flor na boca...

A8(a): Ô sora, aqui quase não tem...

A9(a): Ô sora, tem outra coisa que eu encontrei também. O muro, aqui tá sujo e aqui tá limpo! 
[...] A10(a): Aqui eles estão indo e aqui estão voltando!

P1: É, aqui eles estão indo pro parque e aqui estão voltando...

Além do detido trabalho de comparação de elementos mais salientes ou secundários, pode-se perceber também a emergência de referência e busca de identificação de elementos intertextuais frequentes nos livros de Anthony Browne. Em todas as turmas de crianças, encontram-se leituras imagéticas com menções a outros personagens da cultura retratados e interpretados conforme as experiências dos leitores. Na comparação entre as duas imagens, surgiram referências à Monalisa ("A Monalisa tá chorando!'”; "A Monalisa tá com uma flor na boca”), a Papai Noel, a D. Pedro I ou a um possível pirata, "o cara que faz o Piratas do Caribe” (personagem masculino do quadro) e até a personagens cinematográficos ("Sora, ele parece o King Kong em cima do prédio!”; “Godzilla”). Na turma da segunda escola argentina (EEJB), possivelmente a que tem entre seus alunos alguns provenientes de famílias com mais referências culturais, surgiram menções mais sofisticadas, como a identificação de Mary Poppins (voando com sua sombrinha, em uma diminuta e diáfana imagem) e a quase invisível presença de uma reprodução do quadro “O grito", de Munch, na capa do jornal que o pai de Manchinha lê (Figura $6)$.

É interessante mencionar que, conforme relatado em Chambers (2008, p. 52), uma professora primária inglesa trabalhou de forma produtiva com a mesma obra de Browne, com crianças de 5 a 12 anos e, em uma discussão entre elas (a idade dos interlocutores não é citada), uma criança afirmou: "De todos modos, tu nunca has visto Tarzan y Santa Clos juntos, ni en la $T V$ '. Esta citação aponta para a universalidade desta busca de identificação de personagens e elementos "externos" à narrativa central verbal, sem necessariamente um compromisso com uma explicação estritamente lógica. Além disso, conforme Garralón (2014, p. 20) afirma, o "leitor pode passear, despreocupado por essas referências cultas, sem sua transcendência ser desvelada. O que importa é a presença de um mundo de significados interrelacionados em toda a sua obra".

Neste passeio por algumas leituras infantis das ricas ilustrações de Browne, em Vozes no parque, foi possível verificar o seu caráter desafiador e mesmo aliciador do interesse dos leitores, independentemente de origem social e diversidade de experiências culturais, de tal forma que soa como indiscutível uma afirmação de professora que trabalhou com Vozes no parque: "los cuestionamientos que emergen del texto o ilustraciones pueden llevar al descubrimiento de significados adicionales" (CHAMBERS, 2008, p. 51). 


\section{Considerações finais}

Ao finalizarmos o presente estudo, podemos retomar o que foi colocado na Introdução como seu horizonte: a busca de respostas às seguintes questões - como crianças de diferentes realidades respondem a um mesmo livro ilustrado, por sua vez produzido em outro continente?; o que os dados destes gestos de leitura podem nos ensinar sobre uma mediação adequada em relação a livros ilustrados?

Para buscarmos respostas, mesmo que provisórias a estas questões, aproximamos dados de duas pesquisas, em uma das quais estivemos engajadas e temos acesso à totalidade de dados e outra à qual tivemos acesso apenas através de uma obra publicada, resultante de investigação maior. Malgrado tal limitação, já que o trabalho comparativo não nasceu de uma intencionalidade de aplicação, pensamos que a aproximação entre ambas poderia ser frutífera, considerando a existência de pontos de contato relevantes: o trabalho com um mesmo livro ilustrado, de notável qualidade estética, a semelhança entre idade e nível de escolaridade das quatro turmas envolvidas, o fato se tratar de alunos de escolas públicas e, metodologicamente, a ênfase na conversa grupal mediada sobre as leituras feitas e o acesso de todos os leitores a exemplares da mesma obra.

Obviamente, as mediações de leitura realizadas nas pesquisas, na medida em que acontecem no torvelinho de grupos de crianças ativas, podem diferir bastante, agindo no trabalho de negociações de sentido no contexto escolar. Em alguns momentos, por exemplo, observam-se intencionalidades diversas entre os pesquisadores e em suas formas de perguntar e conversar sobre a obra. Entretanto, entendemos que essa diversidade não prejudicou a emergência das vozes das crianças leitoras. Relembremos que uma experiência de mediação de leitura é única, pois acontece em um momento, em um local, com pessoas - mediador(es) e leitor(es) - atravessadas por interesses, disposições, sentimentos e atitudes diversas.

Mesmo assim, nas análises realizadas, percebemos uma notável confluência de gestos de leitura, tanto no que diz respeito a elementos da estrutura da obra (polifonia, caráter inusitado dos códigos imagéticos das ilustrações) quanto a uma dimensão temática importante - a repercussão da diferença socioeconômica nas relações entre as pessoas, em especial as adultas, resultando no preconceito de classe social, ainda tão presente na atualidade. Em relação a um aspecto inovador da obra - a narrativa de um mesmo episódio, através de quatro vozes -, observaram-se níveis diferentes de sua compreensão, o que seria de se esperar, considerando que as crianças estão habituadas a narrativas com apenas um (1) narrador. Em relação à questão da desigualdade social, ficou evidente, em três dos quatro grupos, uma identificação forte com 
a temática e uma compreensão inclusive afetiva da situação descrita. Já em relação à leitura das ilustrações, com toda a sua complexidade e recursos peculiares do autor, verificou-se um engajamento dos quatro grupos no trabalho de sua apreensão e interpretação. Neste sentido, o comentário de um aluno da Escola 1, feito em linguagem coloquial, parece simbólico. Ao responder à pergunta da mediadora - "Vocês gostaram da história?", ele respondeu: "Sim. Porque ela é bem complicada de entender, e coisas mais complicadas ficam mais tri!"

Salisbury e Styles (2013), ao apresentarem e discutirem resultados de investigação com crianças (de 5 a 11 anos), que leram dois outros livros ilustrados de Browne, verificaram que elas realizaram vários gestos de leitura: responderam a uma interação entre palavra e imagem; analisaram significado das cores; leram linguagem corporal; leram metáforas visuais; observaram e pensaram; enfrentaram desafios oferecidos pelos livros ilustrados; observaram e aprenderam; deram respostas afetivas aos livros. É possível, verificando os dados, concluirmos que também os grupos de crianças brasileiras e argentinas, frente a Vozes no parque, fizeram tudo isto, discutindo significados, ouvindo falando, observando e se aproximando com sentimentos à obra.

É interessante pontuar que os alunos, já no início da apresentação do livro, externavam suas impressões sobre o mesmo; nas duas escolas brasileiras, as primeiras palavras ao terem os livros nas mãos eram: “Que lindo!!!”. Nas sessões de mediação de leitura, ampliaram seus olhares à medida que interagiam com a imagem e a palavra, à medida que observavam o significado das formas, cores e elementos, à medida que pensavam sobre as metáforas visuais, sentindo-se desafiados a analisar a obra e suas diferentes narrativas. No exercício da compreensão leitora da obra, as crianças fizeram várias associações com fatos de suas experiências de vida, rememorando elementos de seus universos culturais, entrando em conflito com valores explicitados na obra e colocando diferentes textos em diálogo.

Deste modo, o estudo permitiu a realização de inferências sobre a universalidade da obra e seu potencial desencadeador de leituras ricas, deflagradas por uma mediação adequada do pesquisador.

[...] compreendemos que a literatura, a cultura e a arte não são um suplemento para a alma, uma futilidade ou um momento pomposo, mas algo de que nos apropriamos, que furtamos e que deveria estar à disposição de todos, desde a mais jovem idade e ao longo de todo o caminho, para que possam servir-se dela quando quiserem, a fim de discernir o que não viam antes, dar sentido a suas vidas, simbolizar as suas experiências. (PETIT, 2009, p. 289).

No entanto, para que os alunos se transformem em participantes ativos desse processo de construir sentidos múltiplos para uma obra, enfatizamos a importância de uma mediação que 
não se revista de um caráter de interrogatório, mas consista em uma conversa desafiadora, planejada, mas flexível, aberta e atenta, como bem acentua Chambers (2007, 2008). Por outro lado, a escolha das obras é essencial, na medida em que livros de caráter comercial e pobres em sua concepção não permitem qualquer trabalho desafiador. E, enfim, é relevante o engajamento do mediador - professor ou bibliotecário - nesta jornada, em especial, considerando que os livros ilustrados de qualidade não se entregam em sua potencialidade a um simples folhear, mas demandam, também do adulto, uma entrega, uma releitura, um trabalho de detetive.

\section{Referências}

ARIZPE, Evelyn; STYLES, Morag. Lectura de imágenes - los niños interpretan textos visuales. México: Fondo de Cultura Econômica, 2004.

BAUER, Martin W; GASKELL, George. Pesquisa qualitativa com texto, imagem e som: um manual prático. Petrópolis: Vozes, 2002.

BROWNE, Anthony. Vozes no parque. São Paulo: ZAHAR, 2014.

CHAMBERS, Aidan. Dime. Espacios para la lectura. Mexico: Fondo de Cultura Econômica, 2007.

CHAMBERS, Aidan. Conversaciones. México: Fondo de Cultura Econômica, 2008.

CORRÊA, Hercules Tolêdo. Qualidade estética em obras literárias. In: PAIVA, Aparecida; SOARES, Magda (orgs.). Literatura infantil: políticas e concepções. Belo Horizonte: Autêntica Editora, 2008. p. 91-109.

GARRALÓN, Ana. Anthony Browne. Revista Emília. Janeiro, 2014. Disponível em: <https://revistaemilia.com.br/anthony-browne/>. Acesso em: 28/04/2020.

GREGORIN FILHO, Jose Nicolau. Literatura infantil: múltiplas linguagens na formação de leitores. São Paulo: Melhoramentos, 2009.

MELLO, M. 2006. Caderno de Pesquisa-Ação Participante. Indicadores Sociais, Serviços Públicos e Movimentos Sociais. Vila Fátima - Bom Jesus. Material Organizado pelo Projeto Abrindo Espaços na cidade que aprende - EJA - Educação de Jovens e adultos - EMEF Nossa Senhora de Fátima. 45 p. (Texto digitado)

NIKOLAJEVA, Maria; SCOTT, Carole. Livro ilustrado: palavras e imagens. Trad. de Cid. Knipel. São Paulo: Cosac Naify, 2011.

NOGUEIRA, Ana Lúcia Horta; LAPLANE, Adriana Lia Friszman. Leitores e leituras: explorando as dobras do (im)possível. In: NOGUEIRA, Ana Lúcia Horta; LAPLANE, Adriana Lia Friszman. Leitores e leituras: explorando as dobras do (im)possível. Campinas, SP: Edições Leituras Críticas; ALB, 2017. p.11-18. 
PAIVA, Aparecida. A produção literária para crianças: onipresença e ausência de temáticas. In: PAIVA, Aparecida; SOARES, Magda (orgs.). Literatura infantil: políticas e concepções. Belo Horizonte: Autêntica Editora, 2008. p. 35-52.

PETIT, Michele. A arte de ler (ou como resistir à adversidade). São Paulo: Editora 34, 2009.

RAMOS, Flávia B.; PANOZZO, Neiva S. Petry. As marcas da palavra e da ilustração. Literatura Infantil. São Paulo: Segmento, 2013. p. 26-37.

THOMSON, Maria Cristina. Sobre líneas. El libro-álbum en el aula. Ilustraciones de Alfredo Grondona White. Buenos Aires: Deldragón, 2016.

SALISBURY, Martin; STYLES, Morag. Livro infantil ilustrado - a arte da narrativa visual. São Paulo: ed. Rosari, 2013.

VAN DER LINDEN, Sophie. Para ler o livro ilustrado. São Paulo: Cosac Naify, 2011.

VERDILE, Laura. "Sobre Líneas. El libro-álbum em el aula": Redescubriendo otros rincones de la literatura infantil. La Primera Piedra. Revista Digital (On line). Mai/2016. Disponível em: https://www.laprimerapiedra.com.ar/2016/05/lineas-libro-album-aula-redescubriendootros-rincones-la-literatura-infantil/. Acesso em 05 de maio de 2020.

Recebido em: 18/05/2020

Aceito para publicação em: 25/08/2020 